ББК 63.4

\author{
Организация конференциии и издание материалов проведень \\ при финансовой поддержке Российского фонда фундаментальных исследований, \\ проект № 19-09-20008
}

Утверждено к печати Ученым советом ИИМК РАН

Редакционная коллегия тома I: В. А. Алёкшин, Л. Б. Кирчо (отв. редакторы),

В. П. Никоноров, В. Я. Стёганцева; В. В. Терёхина

Рецензенты: д. и. н. Л. Б. Вишняцкий, д. и. н. А. А. Выборнов

Программный комитет конференции: академик РАН, д. и. н., проф. М. Б. Пиотровский

(Государственный Эрмитаж, почетный председатель); д. и. н. В. А. Лапшин (ИИМК РАН, председатель); д. и. н. А. В. Головнёв (МАЭ РАН, сопредседатель); д. и. н. В. А. Дергачёв (Высшая антропологическая школа, Молдова, сопредседатель); д. и. н. И. Ф. Попова (ИВР РАН, сопредседатель); академик АН Республики Узбекистан, д. и. н., проф. Э. В. Ртвеладзе (сопредседатель); к. и. н. А. В. Поляков (ИИМК РАН, зам. председателя); к. и. н. В. А. Алёкшин (ИИМК РАН, зам. председателя); д. и. н. Ю. Е. Берёзкин (МАЭ РАН); Dr., Prof. Н. Бороффка (Германский археологический институт, Германия); В. С. Бочкарёв (ИИМК РАН); Dr. Э. Кайзер (Свободный университет Берлина, Германия); к. и. н. М. Т. Кашуба (ИИМК РАН); д. и. н. Л. Б. Кирчо (ИИМК РАН); к. и. н. А. В. Кияшко (Южный федеральный университет); к. и. н. П. Ф. Кузнецов (СГСПУ);

к. и. н. Н. М. Малов (СНИГУ); к. и. н. В. П. Никоноров (ИИМК РАН); Ю. Ю. Пиотровский

(Государственный Эрмитаж); д. и. н., проф. Д. Г. Савинов (Институт истории СПбГУ);

к. и. н. В. Н. Седых (Институт истории СПбГУ); к. и. н. Н. Н. Скакун (ИИМК РАН);

к. и. н. Н. Ф. Соловьёва (ИИМК РАН); к. и. н. А. И. Торгоев (Государственный Эрмитаж); к. и. н. Е. А. Черлёнок (Институт истории СПбГУ)

Организационный комитет конференции: к. и. н. А. В. Поляков (ИИМК РАН, председатель);

к. и. н. В. А. Алёкшин (ИИМК РАН, зам. председателя); В. С. Бочкарёв (ИИМК РАН); ); к. и. н. М. Т. Кашуба (ИИМК РАН); д. и. н. Л. Б. Кирчо (ИИМК РАН);

А. И. Климушина (ИИМК РАН, отв. секретарь); к. и. н. В. П. Никоноров (ИИМК РАН); Ю. Ю. Пиотровский (Государственный Эрмитаж); В. Я. Стёганцева (ИИМК РАН); В. В. Терёхина

(ИИМК РАН, МАЭ РАН, отв. секретарь); к. и. н. Е. С. Ткач (ИИМК РАН); И. Ж. Тутаева (Государственный Эрмитаж); к. и. н. Е. А. Черлёнок (Институт истории СПбГУ)

Древности Восточной Европы, Центральной Азии и Южной Сибири в контексте связей и взаимодействий в евразийском культурном пространстве (новые данные и концепции): Материалы Международной конференции, 18-22 ноября 2019 г., Санкт-Петербург. Т. I. Древняя Центральная Азия в контексте евразийского культурного пространства (новые данные и концепции). К 90-летию со дня рождения патриарха евразийской археологии Вадима Михайловича Массона. - СПб.: ИИМК РАН, Невская Типография, 2019. — 291 с.

ISBN 978-5-907053-34-2

DOI 10.31600/978-5-907053-34-2 
Сарианиди В. И., Бороффка Н. Г. О., Дубова Н.А. 2014. Культурные контакты Маргианы (Туркменистан) в III тыс. до н. э. Новые данные по Гонур-депе (погребение № 4150) // Сарианиди В.И. (гл. ред.). Исследования Гонур Депе в 2011-2013 гг. М. С.127-137 (Тp. МapАЭ. Т. 5).

Salvatori S. 1994. Excavations at the Namazga V late graveyard of Gonur 1 (Murghab delta, Turkmenistan). Preliminary report on the 1993 field season. In: Rivista di Archeologia. Anno XVIII. P. 14-39.

Salvatori S. 1995. Gonur-Depe 1 (Margiana, Turkmenistan): The middle Bronze Age graveyard. Preliminary report on the 1994 excavation campaign. In: Rivista di Archeologia. Anno XIX. P. 5-37.

Schmidt E. F. 1933. Tepe Hissar Excavations 1931. In: Museum Journal. Vol. XXIII, no 4. P. 315-475.

Schmidt E. F. 1937. Excavations at Tepe Hissar, Damgan. Philadelphia.

\section{A DATE OF DESOLATION OF THE ANCIENT AGRICULTURAL CENTER ALTYN DEPE IN SOUTHEASTERN TURKMENISTAN}

Vadim A. Alyokshin

Institute for the History of Material Culture of the Russian Academy of Sciences, St. Petersburg, Russia

Keywords: Central Asia, Northeastern Iran, Aeneolithic, Bronze Age, site, hoard, Altyn Depe, Gonur Depe, Tepe Hissar.

Two "treasures" were found in the uppermost cultural deposit of the Altyn Depe settlement, which dates back to the Eneolithic and Bronze Ages of Southern Turkmenistan. The first one dates according to a bottle (Fig. 1, 1) that is typical for Tepe Hissar IIIB layer, the site in Northeastern Iran (Fig. 1, 2). The second "treasure" dates according to a legged cup (Fig. 1, 5). A similar vessel was found in Burial No. 1450 of the Gonur Depe burial ground (Fig. 1,8) together with a decanter (Fig. 1, 9) having an analogy in Tepe Hissar IIIB layer. Both the "treasures" are associated with the final horizon Altyn $0_{2}$ that is synchronous with Tepe Hissar IIIB layer. Two more artifacts of later times were also discovered at Altyn Depe: a metal rod with the image of a goat's head (Fig. 1,11) and a stone bead with a circle ornament. Similar products are characteristic for Tepe Hissar IIIC layer (Fig. 1, 10, 12, 13). Altyn Depe seems to have been completely abandoned during a period of time synchronous with a transition from Tepe Hissar IIIB layer to Tepe Hissar IIIC layer (Altyn $0_{2} /$ Altyn $0_{1}$ ), that is in the very end of the $3^{\text {rd }}$ millennium BC.

\section{ОТ ДЖЕЙТУНА ДО АНАУ: ТРАДИЦИИ И ИННОВАЦИИ В КАМЕННЫХ ОРУДИЯХ. НОВЫЕ ДАННЫЕ ИЗ МОНДЖУКЛЫ-ДЕПЕ, ТУРКМЕНИСТАН}

\section{Б. Огют}

Институт ближневосточной археологии, Свободный университет Берлина, Берлин, Германия

DOI: $10.31600 / 978-5-907053-34-2-35-38$

Ключевые слова: энеолит Средней Азии, Монджукль-депе, каменные орудия.

В ходе новых раскопок на Монджуклы-депе в Южном Туркменистане в 2010-2013 гг. (Pollock et al. 2019) было собрано в общей сложности 10954 артефактов из некремневых пород камня. Выбранный метод анализа ориентировался на категоризацию этих артефактов (Adams 2002; Wright 1992), исходя из их функций в повседневной жизни обитателей памятника.

В рамках исследования основное внимание уделяется энеолитическому периоду, который, по сравнению с неолитическими слоями, изучен на Монджуклы-депе более детально. 
Сравнительный анализ материалов на региональном и надрегиональном уровнях стал возможен благодаря предыдущему изучению Монджуклы-депе, Чакмаклы-депе, Чагыллы-депе и других памятников региона, отраженному в работах О. К. Бердыева (1966; 1969; 1972), В. М. Массона (1971), и особенно трасологическим изысканиям Г. Ф. Коробковой (1969).

Активное взаимодействие людей и каменных орудий (рис. 1) освещается в ракурсе таких тем, как доступность материала, планирование и случайность при изготовлении и использовании орудий, традиции и инновации в технологическом процессе. С помощью анализа следов использования в большинстве случаев можно определить функциональное назначение артефактов. В то время изготовление таких категорий орудий, как отбойники или терочники, следовало определенным морфологическим нормам. Для некоторых категорий инструментов, используемых при тонких работах (отжимники и лощила), прослеживается широкая вариабельность, указывающая на определенную свободу действий в процессе их производства и использования. Кроме того, изучение использованных в строительстве камней (из вымостки главной улицы и центрального сооружения в виде ворот верхних энеолитических слоев поселения) вносит дополнительную информацию об устройстве, значении и хронологической последовательности возведения этих сооружений, что, судя по всему, требовало значительной организации и затрат времени.

При сравнительном анализе каменных коллекций синхронных памятников проявляются особые виды деятельности обитателей Монджуклы-депе. К таковым относятся изготовление красной краски с помощью специальных краскотерок и ее широкое использование в отделке домов, судя по остаткам охры на полах и стенах помещений, а также в погребальном обряде.

Биографический подход к изучению объектов позволяет за самими объектами увидеть особенности жизни индивидуальной и коллективной людей, которые ими пользовались.

\section{Литература}

Бердыев О. К. 1966. Чагыллы-депе - новый памятник неолитической джейтунской культуры // Кисляков Н. А., Воробьева М. Г. (отв. ред.). Материальная культура народов Средней Азии и Казахстана. М. С. 3-28.

Бердыев О.К. 1968. Чакмаклы-депе - новый памятник времени Анау Ia // Виноградов А. В., Воробьёва М. Г. и др. (ред.). История, археология и этнография Средней Азии. М. C. 26-34.

Бердыев О. К. 1972. Монджуклы-депе - многослойное поселение неолита и раннего энеолита в южном Туркменистане // Каракумские древности. Вып. 4. С. 11-34.

Коробкова Г.Ф. 1969. Орудия труда и хозяйство неолитических племен Средней Азии. Л. (МИА. 158).

Массон В. М. 1971. Поселение Джейтун. Проблемы становления производящей экономики. Л. (МИА. 180).

Adams J. L. 2002. Ground Stone Analysis. A Technological Approach. Salt Lake City.

Pollock S., Bernbeck R., Öğüt B. (eds.). 2019. Looking Closely. Excavations at Monjukli Depe, Turkmenistan, 2010-2014. Leiden.

Wright K. I. 1992. A Classification System for Ground Stone Tools from the Prehistoric Levant. In: Paléorient. Vol. 18. No 2. P. 53-81. 


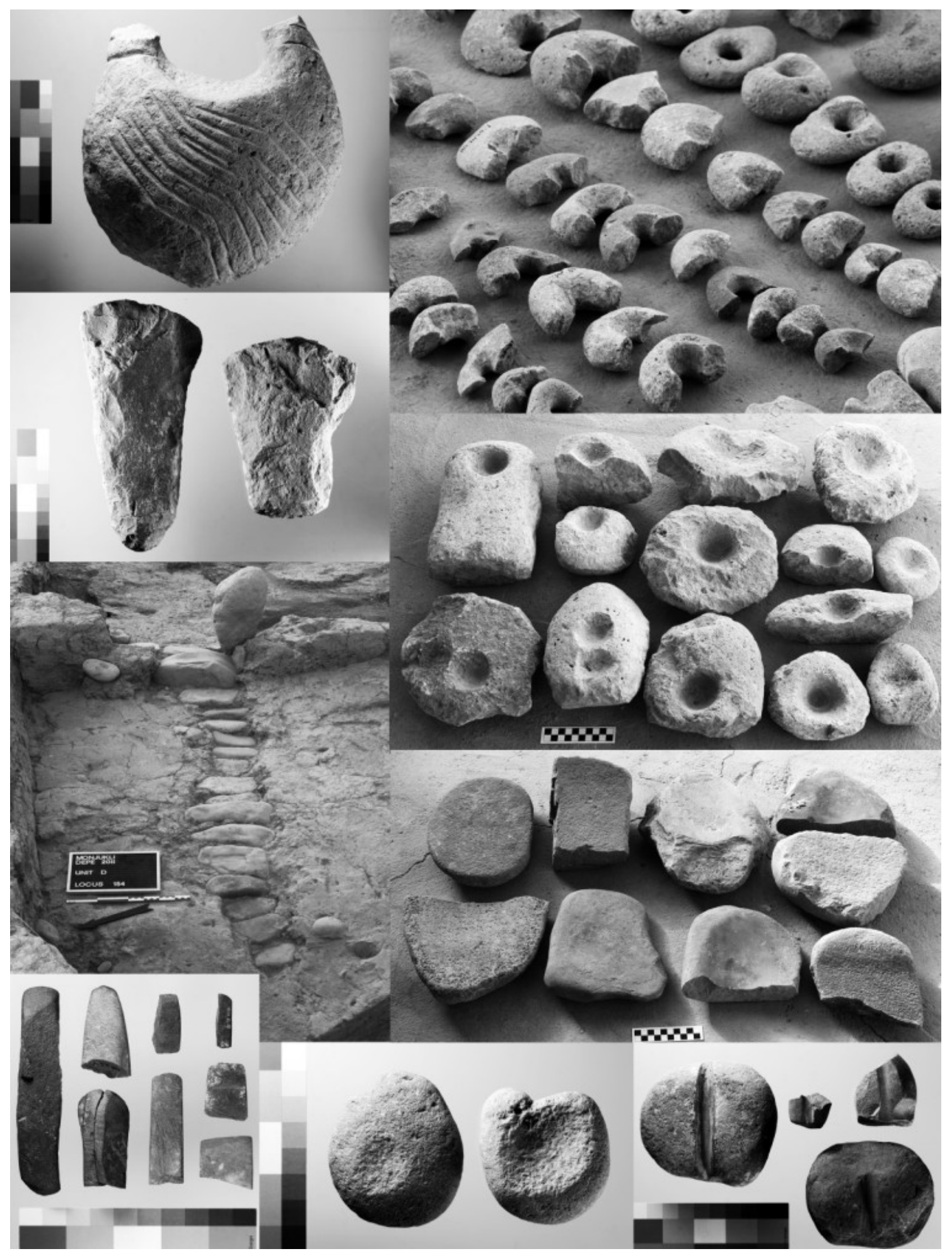

Рис. 1. Монджуклы-депе, Туркменистан, каменные орудия из некремневых пород 


\title{
FROM JEITUN TO ANAU: TRADITIONS AND INNOVATIONS IN GROUND STONES. NEW DATA FROM MONJUKLI DEPE, TURKMENISTAN
}

\author{
Birgül Ögüt \\ Institut für Vorderasiatische Archäologie, Freie Universität, Berlin, Germany
}

Keywords: Aeneolithic of Middle Asia, Monjukli Depe, ground stone artefacts.

New excavations of Late Neolithic and Early Aeneolithic layers at Monjukli Depe yielded a collection of approximately 10000 ground stone artefacts (Fig. 1). Contextual information, traces of use, residues, and morphology provide a broad insight into the everyday life of the local inhabitants. Details offer information not only about material changes during this period, but also about the social structure within the settlement. Thus, the ground stones of Monjukli Depe give a basis for consideration on a broader chronological or regional level. Some results support the already established interpretations in the field of ceramics and architecture, such as egalitarian structures pointing to autarkic households. New observations, however, indicate a greater local continuity in the development of technologies from the Late Neolithic to the Early Aeneolithic, which is not exclusively due to external impulses.

\section{ИЗУЧЕНИЕ ДРЕВНЕЙ ИСТОРИИ АФГАНИСТАНА В ТРУДАХ В. М. МАССОНА}

\section{Р. Я. Шарифов}

Таджикский национальный университет, Душанбе, Таджикистан

DOI: 10.31600/978-5-907053-34-2-38-40

Ключевые слова: земледельческие культуры, иивилизации, археологические изыскания, Афганистан, Индия, Иран.

В. М. Массон является одним из выдающих ученых XX - начала XXI в., с именем которого связано изучение древних цивилизаций. Будучи истинным интеллектуалом, он обладал настоящим археологическим чутьем, что позволило ему отметить Афганистан как один из очагов древнейшей цивилизации, хотя там он никогда не был и не проводил археологические изыскания.

Отличие Афганистана от других стран Азии заключается, в первую очередь, в своеобразии его исторического пути. Афганистан не являлся колонией европейских стран и меньше попал под воздействие европейского культурного влияния. Это привело к тому, что Афганистан долгое время был закрытой страной, в ней намного позже стали проводится археологические изыскания, преимущественно французскими и английскими археологами. В стране находились крупнейшие памятники истории - Бамиан, Балх, Герат и т. д., свидетельствующие о богатом историческом прошлом. В древних письменных источниках имеются сведения о том, что Великий Шелковый путь проходил по территории Афганистана, который входил в состав Ахеменидского государства. Через Афганистан продвигались войска Александра Македонского по пути в Индию. Местные жители показывали европейцам древние крепости и остатки крепостных стен, а находки старинных монет, статуй и других предметов свидетельствовали о том, что эта земля скрывает немало тайн прошлого, о которых практически ничего не было известно. Проводившиеся европейскими археологами раскопки открывали в Афганистане множество каменных орудий, однако древнейшая история страны меньше интересовала археологов, чем античные города и поселения. Тщательно изучив всю археологическую литературу, В.М. Массон подчеркнул, что природные условия Афганистана (наличие больших рек, благоприятный климат, близкий природным условиям Северо-Западной Индии) указывают на то, что 